\title{
Coupling Corporate Social Responsibility into Millennium Development Goals is a Mere Wishful Thinking?
}

\author{
Martha Fani Cahyandito \\ Center for Management and Business Studies (LP3M) \\ Faculty of Economics and Business, Universitas Padjadjaran \\ Jalan Cimandiri No. 8, Bandung 40115, Indonesia \\ Tel: 62-22-423-9954 E-mail: cahyandito@yahoo.com
}

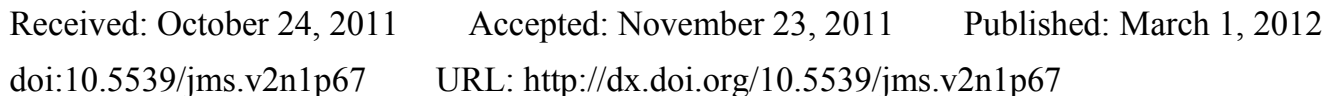

The research is financed by the Directorate for Higher Education, Ministry of Education and Culture of the Republic of Indonesia through the Program Academic Recharging 2011.

\begin{abstract}
The purpose of this study is to explore the opportunity of building the synergy between the government and private sector to accelerate the achievement of Millennium Development Goals (MDGs) through Corporate Social Responsibility (CSR). From the content analysis, the indicators of CSR from various CSR Guidelines have the same motives and goals with those of MDGs. This indicates that CSR can be harmonised with government programs to achieve the MDGs. The individual and external environment aspect has less significant effect; institutional aspect becomes the central of attention in this study. The harmonisation mechanism between government and private sector in Indonesia is formulated through focus group discussion. The development programs designed by Indonesian government should comply with the principles of German government in AP 2015. Other countries can benefit this study that has same goal to achieve MDGs in 2015.
\end{abstract}

Keywords: Millennium Development Goals, Corporate Social Responsibility, Institutional aspect

\section{Introduction}

\subsection{Research background}

Deadline for the achievement of Millennium Development Goals (MDGs) in 2015 is in sight. Many targets had been reached by Indonesia, but some homeworks remain to be done to meet all the MDGs (Bappenas 2010). Aspect of limited government funding is seen to be an obstacle in achieving this. Therefore it is necessary to find a strategy to cope with this challenging situation.

One of the high potential schemes for synergy with Indonesian government programs for the MDGs is the Corporate Social Responsibility (CSR) organised by corporation. However, the achievement of MDGs in Indonesia can apparently be faster achieved if Indonesia pursues its efforts not only with all resources it has, but also with cooperation with other countries. Germany, as one of developed countries, was one of the first donors that developed Action Program (AP) 2015 in April 2001in helping developing countries attaining their MDGs. Through AP 2015, assistance provided by Germany is not only limited to financial aid, but moreover also in the form of tactical assistance (BMZ 2005a, 2005b). That is why Germany is selected in this study as a sample from donor countries in order to explore what should be adapted from the AP 2015 so that Indonesia can cooperate with Germany in pursuing the MDGs.

\subsection{Research goals}

Some research questions appear in this study:

1) Is CSR generally feasible to be harmonised with MDGs from the theoretical point of view?

2) Who are the actors of CSR in Indonesia from the business responsibility point of view?

3) How should the harmonisation mechanism between Indonesian government and private sectors look like? 
4) What should be done by the Indonesian government if they want to cooperate with developing country to accelerate the achievement of MDGs in Indonesia?

\section{Conceptual and theoretical background}

\subsection{Millennium development goals}

There are eight goals (with each own targets) of the MDGs that must be fulfilled by countries in the world in 2015, which are (UN Millennium Project 2005):

- MDG 1: Eradicating poverty and hunger

- $\quad$ MDG 2: Basic education for all

- MDG 3: Encouraging gender equality and empowerment of women

- MDG 4: Reduce child mortality

- MDG 5: Improve maternal health

- MDG 6: Combat HIV/AIDS, malaria and other infectious diseases

- MDG 7: Ensure environmental sustainability

- MDG 8: Building a global partnership for development

To achieve all eight goals of MDGs is surely not an easy task for developing countries. Because of the difficulty of the struggle to achieve MDGs, Jeffrey D. Sachs expresses “...achieving the Millennium Development Goals will require a global partnership suitable for an interconnected world" (UN Millennium Project 2005:x). The German Chancellor Gerhard Schröder has stated in the year 2001 for Program of Action 2015:

"Extreme poverty, growing inequality between countries, but also within countries themselves, are great challenges of our times, because they are a breeding ground for instability and conflict. So reducing worldwide poverty is, not least, essential to safeguarding peace and security" (Source: UN Millennium Project 2005:10)

German government responded to this quickly and decisively to become the first donor country to create strategies to achieve the MDGs to help developing countries with the Programme of Action 2015 (AP 2015). AP 2015 is considered as crosscutting strategy, because all created agenda and programs are directed toward the alleviation of poverty (MDG Goal 1). By alleviating poverty, it is expected that automatically all the other MDGs will be resolved gradually (BMZ 2005b).

To succeed the AP 2015, German government prepared a guideline so that the cooperation conducted between Germany and other donor countries with developing countries can be effectively implemented, namely that cooperation should be undertaken: (1) Based on the principle of Partnership and Shared responsibility, (2) Result oriented (Efficiency), and (3) Promoting coherence between institutions. German Federal Ministry for Economic Cooperation and Development plays an important role in this sense (UNDP 2011, BMZ 2005b).

Actually, MDGs are not new for Indonesia, because Indonesia has long been carrying out development programs in the food sector, health and family planning, etc. packaged in the Five-Year Development Programs Plan (REPELITA). This program contains intensive efforts to balance between economic and social program. Since then, significant progresses are achieved, but the financial crisis in the late 90s was a downturn in the economic and social status. In 2000, the Indonesian government started to take shape on various basic policies in the national development, which is also related to MDGs (Murniningtyas and Widyono 2008).

Indeed, there are some targets of MDGs which have experienced a significant increase, and which has been reached, but there are also several targets of MDGs which still have to work hard to achieve it such as poverty reduction (MDG 1), reduction of maternal mortality (MDG 5), and reduction of greenhouse gas and carbon dioxide emission, eliminating illegal logging, as well as improvement of sanitation and access to water supply (Bappenas 2010).

Therefore an idea appears that there must be a breakthrough for efforts to accelerate the achievement of the MDGs in this remaining 4 years. The idea is the harmonisation of government program with the CSR from private sector to accelerate the attainment of MDGs, not only internally in Indonesia but also externally with Germany. This is because there was a statement from the Federation of German Industries (BDI) that achieving the MDGs is only possible through economic growth backed by private engagement and BDI has a big concern on it (BDI 2011, CSR Germany 2011). So, here it can be seen that the German industry recognises that the participation of the private sector in helping the government to achieve the MDGs is very large. 


\subsection{Business ethics and responsibility}

However to explore the actors and their responsibilities in supporting the achievement of MDGs, business ethics and responsibility approach is applied. The breadth of the topic "business ethics", as defined above, means that other related ideas like Corporate Social Responsibility (CSR) and Corporate Citizenship (CC) and sustainability are in fact sub-topics within the broader topic of business ethics (MacDonald 2010).

Business ethics can be defined as the critical, structured examination of how people \& institutions should behave in the world of commerce. In line with the development of stakeholder theory, business ethics also use stakeholder's perspective, where companies have certain duties not only to the best interest of the owner (including company's investors) on maximising company's profit but also to groups outside its financial operations whose needs should be taken into consideration (Gruble 2010).

From a philosophical standpoint, business ethics contains several responsibilities that are formed from the three forms of relationships, namely (Höffe 1993:23):

1) The responsible subject is designated to the person who is responsible for something.

2) The responsible object or responsible area refers to what will be in charge, and includes the act and the intended and unintended consequences and side effects.

3) The responsible authority refers to those "institutions" that have to take responsibility over the subject of responsibility.

4) The "norm background" refers to norms and rules that allow to ascribe the agent responsible for something and against someone.

\subsection{Corporate social responsibility}

The breadth of scope of business ethics definition, as defined above, makes other related ideas like CSR and CC fall into sub-topics of business ethics (MacDonald 2010, Weiss 2005). It is simply the concept of holistic orientation of the company to the principles of civil society in which every citizen "feels obliged to the good of society as a whole" (Ulrich and Kaiser 2001:29). What it means is that companies are a part of society and should behave as one, as would be expected from a good citizen of a country (Assländer 2011). Thus, the core business of the company has to refer to the respectful treatment of the company and its stakeholders, or a socially- and environmental-friendly business policy.

From the literature study it can be clearly described that CC can be viewed in Germany as an aspect of CSR. The understanding of CSR is gaining many responses as the umbrella of the CC concept in the German debate. Similar with Germany, the term of CSR is more popular in Indonesia among academicians, bureaucrats, and practitioners (Weber in Mueller and Schaltegger 2008, Kaiser and Schuster 2004).

Kotler and Lee (2005:3) stated "corporate social responsibility is a commitment to improve community well-being through discretionary business practices and contributions of corporate resources". Furthermore, World Business Council for Development Sustainable (WBCSD) illustrates that:

"corporate social responsibility as 'business' commitment to contribute to suistanable economic development, working with employees, their families, the local community, and society at large to improve their quality of life" (Kotler and Lee 2005)

Now the CSR is increasingly a concern among business people and entrepreneurs. They are trying to implement CSR for a variety of reasons. There is a fear of losing prestige, or simply went along because the competitors do the same. Some are implementing in the framework of compliance with the provisions of legislation, as has been practiced by state-owned enterprises (SoEs) through partnership and community development program (Wieser 2005, van Marrewijk 2003).

CSR has turned out to be one of the most persistent "management fashions" and considered as an increasingly necessary practice. Pressures to the effort to implement CSR is raising, where the corporation is no longer solely engaged only for profit, but also has to set aside a certain part of its profits to CSR activities to provide maximum benefit for the public interest, especially the stakeholders (Keinert 2008).

Company's participation in implementing CSR can provide many benefits for companies, among others:

- increase the company's image and influence,

- strengthen brand positioning,

- increase the desire for investors to invest, 
- improving ability to captivate, motivate, and retain employees,

- increase sales and market share

However, implementing CSR cannot be said as a simple matter since there are some things that can be drivers/barriers for companies to implement CSR, namely: individual aspect, institutional aspect, and external environmental aspect (Keinert 2008).

\section{Methodological framework}

Literature study dan content analysis are conducted on indicators of CSR from various CSR Guidelines (ISO 26000, Global Reporting Initiative, Global Compact, OECD Principles for Multinational Corporation, Global Sullivan Principles, Caux Round Table Discussion, Equator Principles) to assess whether CSR can be harmonised with the MDGs conceptually. The harmonisation mechanism between the Indonesian government and private sectors is formulated by conducting focus group discussion (FGD) with numerous ministries, NGOs, state-owned and private companies in Indonesia. Literature study is also conducted to explore what should be done by Indonesian government to cooperate efficiently with Germany in accelerating the achievement of MDGs.

\section{Results and discussion}

\subsection{The implementation of CSR in Indonesia}

In Indonesia, CSR is viewed as the implementation of the concept of sustainable development by the business. Indonesian government even issued regulations related to CSR which is Government Law No. 40/2007 about the Public-listed Company in which Article 1 Clause 3 states: "social and environmental responsibility is the company's commitment to participate in sustainable economic development in order to improve the quality of life and environment that are useful, both for his own company, local communities, and society at large" (BUMN Track 2011).

Indonesian companies who are engaged in the exploration/exploitation/ management of natural resources is bound by regulations in Article 74 Paragraph 1 of Government Law on Public-Listed Companies in 2007 that said "a corporation carries on business in the field of and/or relates to natural resources, is required to run the social and environmental responsibility" (BUMN Track 2011).

CSR is becoming a trend and more companies in Indonesia are implementing the program. In its development, in the scope of Indonesian state-owned enterprises, new terminology raised: Partnership Program and Community Development (In Indonesian Language: Program Kemitraan dan Bina Lingkungan or PKBL). PKBL refers to the Regulation of the Minister of State-owned Enterprises (SoE) No. Per-05/MBU/2007 about PKBL which was established on 27 April 2007. Partnership Program (PK) is business cooperation program that is oriented more on business development which is based on partnerships between the corporate (mainly SoEs) with Micro Small and Medium Enterprises to improve the ability of small businesses to become strong and independent. Meanwhile, BL is the empowerment program of social conditions of the society in the form of assistance to victims of natural disasters, education and/or training, health improvement, development of public facilities and infrastructure, places of worship, or nature conservation (Ferdian 2008a, 2008b).

CSR and PKBL are similar but not identical. The sense is almost identical, which is social and environmental responsibility, but they have different funding sources. The funding for CSR is managed by the company itself and taken from the company's operating costs. Meanwhile, the PKBL is calculated from the profit of the company. PKBL is simply a part of CSR, which is undertaken by state-owned enterprises (MihradiCendikia 2008, Faqih 2010).

CSR and PKBL in Indonesia can be done in various ways such as direct involvement, through foundation or social organisation within the company, partnering with other party, and also by supporting or joint in a consortium (Saidi and Abidin 2004:64-65).

Many companies in Indonesia who have been doing CSR in the economic, social, and environment have tasted a variety of benefits. The Indonesian government also held a CSR Award for companies that have implemented CSR well and giving positive impact on society at large, and also the MDGs Award for local governments that have succeeded in achieving the MDG targets significantly. Various facts on the ground show that private companies with a wide variety of CSR activities can work hand in hand with the governments to help achieve the MDGs.

In addition to that, the government of Indonesia also encourages companies to do CSR by providing tax exemption and deduction through a few government regulations related to Income Tax and Value Added Tax 
(Effendi 2010).

\subsection{The implementation of CSR in Germany}

In Germany there is an institution called CSR-Germany as representation of German industries which is composed of several organisations namely BDA (Confederation of German Employers' Association), BDI (Federation of German Industries), DIHK (Association of Chambers of Industry and Commerce), and ZDH (German Confederation of Skilled Crafts). For German industries, CSR is not a new development whereas a commitment to society is a fixed component of German business culture. The German government has officially acclaimed the definition of CSR from the European Community where CSR is "an effort where companies integrate social and environmental concerns in their business operations and in their interaction with their stakeholders on a voluntary basis" (EC 2001).

CSR for the German industries are (Loew 2005):

- CSR is a company's contribution to sustainable development.

- CSR embraces social and environmental responsibility.

- A dialogue with the stakeholders is embedded in CSR.

- CSR is a voluntary engagement and no legal enforcement is to be anticipated.

- CSR is company specific and its implementation will vary from organisation to organisation (cannot be 'one-size-fits-all' solution).

However, the German industry acknowledges some opportunities and/or limitations of CSR. They said that: "Many companies are actively involved in solving weighty societal problems, especially in emerging and developing countries. Through their CSR activities, companies can make an important contribution to sustainable development, also in partnership with other players in society. Companies can complement the efforts of politicians for development of society and social progress through their commitment, but cannot substitute for them. This task cannot be delegated to companies. This would amount to a privatisation of law enforcement" (Loew 2005).

\section{Conclusion remarks}

Deadline for the achievement of MDGs in 2015 is in sight. Many of the targets had been reached by Indonesia, but there are also some homeworks remain to be done to meet all the MDGs. Aspect of limited government funding is seen to be an obstacle in achieving this. To response to this challenge, some conclusion remarks are drawn as research answers:

1) Exploring a variety of guidelines related to CSR such as the Global Compact, Caux Round Table Discussion, GRI, ISO 26000, Global Sullivan Principles, Equator Principles, OECD Principles for Multinational Corporation, it can be seen that in general CSR can be harmonised with the government programs in achieving the MDGs because the indicators between those two variables are related to one another (see i.e. ISO 2010, GRI 2010).

2) Based on the principles of responsibility in the business ethics discussion (responsible subject, responsible object, responsible authority, and background norm), the Indonesian government, who has signed a commitment to the UN Millennium Summit in 2000, is responsible to meet the MDG targets until the year 2015, without any pressure from any side so that no institution has the right to conduct surveillance except the awareness of the Indonesian government and relevant parties in meeting the various norms and values in the economic, social (human rights, labor, gender, etc.), and environment.

However, it must be bared in mind that various parties in Indonesia including both state-owned enterprises implementing PKBL as well as private companies with their CSR (and maybe other parties) must cooperate to raise the standard of human welfare of Indonesia in accordance with the MDGs. Therefore, in the case of Indonesia, CSR and PKBL can be utilised as important instruments to accelerate the achievement of the MDGs. CSR and PKBL can be utilised not only to accelerate the targets of MDG which are still not yet achieved, but also for those which have been attained. Nevertheless, the priority is obviously on those targets which have not been yet achieved.

3) It must be recognised that implementing CSR is not a simple thing. Many aspects are underlying company's desire to implement CSR, such as individual, institutional, and external environmental aspect. The individual aspect has very less significant effect in this study. This is slightly different from the external environmental aspect. If viewed from the perspective of external environmental aspect, government regulations may be the driver for companies to implement CSR. 
The individual and external environmental aspects are considered less significant in this study. What should be taken into consideration for the external environmental aspect, are the rules that can facilitate or hamper the efforts of various parties (institutions) in achieving the MDGs. In other words, the major concern is the institutional aspect (who is doing what) as further described below.

Harmonisation mechanism to accelerate the achievement of MDGs through CSR and PKBL is as follows:

- The central government set the Roadmap of Achievement Acceleration of MDGs which will be used as a reference for private parties to participate in implementing the acceleration of the achievement of MDGs in Indonesia. The central government passes the strategy to the local government through Bappeda. Bappeda plays a role as coordinator in the local level. The provincial government set up "Regional Action Plan in Accelerating the Achievement of MDGs" which is used as a basis for planning, improving coordination of efforts to reduce poverty and improve people's welfare.

- The government identifies programs and activities in "Regional Action Plan in Accelerating the Achievement of MDGs" whose implementation can be harmonised with the activities of CSR (which can be funded by the private sector) and which are not (CSR, PKBL, or other sources).

- Government identifies companies that have implemented CSR and PKBL. At this stage, it is simply to identify companies that operate or adjacent to the area. The output of this step is a list (long-list) of companies implementing CSR/PKBL programs, and also list of companies that do not regularly carry out CSR programs but have the concern of CSR and can be asked to work together (usually a local scale company that has been fairly well established). (Note: The list of companies shall not be disseminated as public information, but only for government consumption in order interlacement cooperation for the achievement of MDGs).

- The government makes the initial rating and sorts it based on the level of business relevance to the MDGs to be achieved. The ordering over the company is intended to set priorities that will be contacted. The output of stage 1 to 4 is such a document that can be used as a base to communicate to the companies in which the government program for MDGs and activities of CSR/PKBL can be harmonised.

- The government makes an approach to the companies running CSR/PKBL (socialisation and communication) that have been determined in the previous stage. The government is trying to convince the companies to synergise its CSR/PKBL activities in the public interest. Here the communication strategy and professional mediation is needed in order to realise the synergies of CSR/PKBL activities and to avoid the negative concern from the companies that CSR/PKBL is only used as a tool by the government to make the private sector as cash cow to fund government programs.

- Government and private sector establish systematic communication. If necessary, the government can involve the intended company in the formulation of communication strategies in particular. This process is important in order to build a framework of cooperation based on shared understanding and responsibility.

- Government and private sector collaborate on an ongoing basis. The sense of mutual understanding of common interests is raised so that cooperation can be established, either during the implementation phase as well as in monitoring / evaluation (monev). It is characterised by the process of expanding the coverage (scaling up) both in terms of quantity and quality of achieving the MDGs, particularly those funded by the CSR/PKBL. This condition is the final target of government partnerships with companies in directing CSR/PKBL to the achievement of the MDGs.

The Indonesian government must be very careful in approaching cooperation with private companies. The prudence of the government to offer the harmonisation mechanism of financing and implementation of CSR by private parties must be observed to hinder the negative thought from the private sector that this harmonisation program is only a means to give added weight to the private sector. Therefore, governments need to precede an approach in such a way to the private sector, in this case the company, in order to motivate them to work together and harmonise the MDGs and CSR programs.

In addition, the Local Agency for Development Planning in the Provincial level should be able to act as coordinator for the harmonisation of the implementation of CSR to support the achievement of the MDGs, but still the implementation of CSR is left to the company itself. The coordination of government and corporation in the framework of this harmonisation is very important to avoid the overlapping agenda of CSR implementation. Furthermore, such harmonisation can also reduce the blankspot of CSR implementation. It means that by 
conducting the coordination (between government and corporations) and harmonisation of the program/ activities of CSR, the coverage area of CSR can be widen and more Indonesian people can take the benefits of CSR.

The local government should create a document of action plan which emphasises the program and activities to be offered and to be harmonised with the private sector. From this document the government may be self-informed, which activities can be done by itself and which activities can be done by the corporations. After the government established this document, the approach to the firms takes place. The approach to the firms should be open and professional. The approach can take the form of:

- $\quad$ Publication of the website: Government publishes the mapping document in the website so that companies can access and take information from it,

- $\quad C S R / P K B L$ Exchange: Government meet corporations in such CSR/PKBL Exchange,

- $\quad$ Door-to-door-approach: Government can do the door-to-door-approach to corporations to establish direct communication.

4) The achievement of MDGs in Indonesia will certainly be more rapid if Indonesia can cooperate with other countries especially the developed countries such as Germany. The German industries have opened the door wide open for cooperation with the developing countries as mentioned by the 'CSR-Germany's objectives namely that the 'CSR Germany wants to link up with a network in order to promote the exchange of experience and to present their CSR activities to a wider public. Consequently, if Indonesia wants to cooperate with donor countries such as Germany, then the thing to note is that the development programs designed by the government of Indonesia must comply with the principles as has been stated by German government in AP 2015 for helping developing countries in achieving the MDGs. The designed programs should be: (1) Based on the Principle of Partnership and Shared Responsibility, (2) Result-oriented (Efficiency), and (3) Promoting coherence between institutions. That way, Germany and other donor countries would be easier to provide assistance, not only in a material form but also technical and personal improvements as well as institutional capacity building.

\section{References}

Assländer, M. S. (2011). Grundlagen der Wirtschafts- und Unternehmensethik. Marburg, Metropolis Verlag.

Bappenas (Badan Perencanaan Pembangunan Nasional Indonesia/National Agency for Development Planning of the Republic of Indonesia). (2010). Summary of the Roadmap to Accelerate Achievement of the MDGs in Indonesia. Document of National Agency of Development Planning of the Republic of Indonesia.

BDI (Bundes Deutschen Industrie/Federation of German Industries). (2011). Development Policy: Development Cooperation. [Online] Available: www.bdi.eu/bdi_english/2836.htm (September 23, 2011).

BMZ (Bundesministerium für wirtschaftliche Zusammenarbeit und Entwicklung/German Federal Ministry for Economic Cooperation and Development). (2005a). Germany's Contribution to Achieving the Millennium Development Goals. Information Materials of BMZ, Bonn/Berlin, January 2005.

BMZ (Bundesministerium für wirtschaftliche Zusammenarbeit und Entwicklung/German Federal Ministry for Economic Cooperation and Development). (2005b). Enhanced Aid Effectiveness: Focusing German Development Cooperation on the Millennium Development Goals: Implementing the Paris Declaration on Aid Effectiveness. Documents of German Federal Ministry for Economic Cooperation and Development, August 2005.

BUMN Track. (2011). Mitra Media PKBL BUMN: Tanggung Jawab Sosial Di Dua Kaki. [Online] Available: http://bumntrack.com/index.php/home/mitra_detail/193 (October 21, 2011).

CSR Germany. (2011). Die Initiative. [Online] Available: http://www.csrgermany.de/www/csr_cms_relaunch.nsf/res/CSR-Germany.pdf/\$file/CSR-Germany.pdf (September 17, 2011).

EC (European Commission). (2001). Promoting a European Framework for Corporate Social Responsibility, Green Paper.

Effendi, S. (2010). Evaluasi Aspek CSR dalam Perpajakan Indonesia (Evaluation of Aspects of CSR in Taxation System in Indonesia). Indonesia Tax Review, Vol. III/ Edition 19/2010.

Faqih, M. (2010). Satu Tujuan Beda Sumber Dana. [Online] Available: http://bataviase.co.id/node/148359 (October 21, 2011). 
Ferdian, A. (2008a). PKBL BUMN, CSR-kah? [Online] Available: http://pkblbumncsrkah.blogspot.com (October 21, 2011).

Ferdian, A. (2008b). Kesimpulan Lokakarya Pasal CSR \& PKBL. [Online] Available: http://resume-seminar-pasal-csr-pkbl.blogspot.com (October 21, 2011).

GRI (Global Reporting Initiative). (2010). Sustainability Reporting Guidelines G3.1 (Version 3.1), Document of the Global Reporting Initiative, Amsterdam, The Netherland.

Gruble, C. (2010). A Definition For Business Ethics. [Online] Available: http://christinagruble.articlesbase.com/business-articles/a-definition-for-business-ethics-1831317.html (October 5, 2011).

Höffe, O. (1993). Moral als Preis der Moderne. Frankfurt am Main, Suhrkamp Taschenbuch Verlag.

ISO, 2010, ISO 26000. Social Responsibility: Discovering ISO 26000. ISO Central Secretariat, Genève, Switzerland.

Kaiser, S., and Schuster, M. (2004). Corporate Citizenship: Eine betriebswirtscahftliche Betrachtung des gesellschaftlichen Engagements von Unternehmen. WiSt, 33 (11): 669-672.

Keinert, C. (2008). Corporate Social Responsibility as an International Strategy. Heidelberg, Physica-Verlag.

Kotler, P., and Lee, N. (2005). Corporate Social Responsibility: Doing the Most Good for Your Company and Your Cause. New Jersey, John Wiley \& Sohns.

Loew, T. (2005). CSR in der Supply Chain: Herausforderungen und Ansatzpunkte fur Unternehmen. Vorbereitungspapier fur den 5.Multistakeholderworkshop zu CSR (gefordert durch das Bunderministerium fur Umwelt, Naturschutz und Reaktorsicherheit). Diskussion Paper 4 Sustainability, Berlin.

MacDonald, C. (2010). Ethics Definition. [Online] Available: http://businessethicsblog.com/2010/03/21/ethics-definition (October 5, 2011).

Murniningtyas, E., and Widyono. (2008). MDG Indonesia: Status and the Way Forward. Paper Presented at the UN-DESA UN-ESCAP MDG Workshop, Bangkok, 20-22 August 2008.

Saidi, Z., and Abidin, H. (2004). Menjadi Bangsa Pemurah: Wacana dan Praktek Kedermawanan Sosial di Indonesia. Jakarta, Piramedia.

Ulrich P., and Kaiser, M. (2001). Das Unternehmen, ein guter Buerger: Corporate Citizenship im Zeichen gesamtgesellschaftlicher Mitverantwortung. New Management, 70 (12): 25-31.

UN Millennium Project (2005). Investing in Development: A Practical Plan to Achieve the Millennium Development Goals. New York.

UNDP (2011). Millennium Development Goals: How does UNDP work with donor? [Online] Available: www.undp.org/mdg/donors.shtml (September 23, 2011).

Van Marrewijk, M. (2003). Concepts and Definitions of CSR and Corporate Sustainability: Between Agency and Communion. Journal of Business Ethics, 44, 95-15. http://dx.doi.org/10.1023/A:1023331212247

Weber, M. (2008). Corporate Social Responsibility: Konzeptionelle Gemeinsamkeiten und Unterschiede zur Nachhaltigkeits- und Corporate-Citizenship-Diskussion. In Müller, M., und Schaltegger, S. (Eds.), Corporate Social Responsibility: Trend oder Modeerscheinung? München, oekom Verlag, p. 39-51.

Weiss, R. (2005). CSR und Corporate Citizenship: Strategien gesellschaftsorientierter Unternehmenskommunikation. In Michelsen, G., and Godemann, J. (Eds.), Handbuchnachhaltigkeitskommunikation: Grundlagen und Praxis, München, oekom Verlag, p. 588-598.

Wieser, C. (2005). CSR - Ethik, Kosmetik oder Strategie? Über die Relevanz der sozialen Verantwortung in der strategischen Unternehmensführung. Wien, LIT Verlag. 